\title{
Cohesion and Coherence of Narrative Essays of Madagascar Students of Indonesian Language for Foreign Speakers (BIPA) at UPTP2B Sebelas Maret University
}

\author{
Basuki Rachmat Sinaga ${ }^{1}$, Andayani ${ }^{2}$, Sahid Teguh Widodo ${ }^{3}$ \\ ${ }^{1,2,3}$ Sebelas Maret University, Indonesia \\ basukisinaga@yahoo.co.id, buanda09@yahoo.co.id, sahidteguhwidodo@yahoo.com
}

\begin{abstract}
This study aimed to describe the use of the form of cohesion and coherence of narrative essay of Madagascar students of Indonesian Language for Foreign Speaker (BIPA) at Language Center Sebelas Maret University. The method used was descriptive qualitative. The researcher collected the data by giving assignments to the students. Then, the researcher classified the findings with the techniques of reading, listening, and writing. The results obtained in the form of cohesion were: 1) grammatical cohesion consisted of reference, substitution, ellipsis, and conjunction; 2) lexical cohesion consisted of repetition, synonym, and collocation. In the form of coherence, the students were able to express their writing in a simple way to be able to be understood by the readers.
\end{abstract}

Keywords: BIPA, Cohesion and Coherence, Narrative Essay.

\section{Introduction}

Indonesian Language for Foreign Speakers $(B I P A)$ is a language learning program for foreign speakers who are not native speakers of Indonesian language. This program is being promoted in the context of the internationalization of Indonesian language as a friendship language. At present, many countries are interested in opening BIPA programs, such as, Japan, Vietnam, Canada, South Korea, the United States, including Australia which requires 500 schools to learn Indonesian language (Destiani, Andayani \& Muhammad Rohmadi, 2018).

It is not only conducted abroad, but also in Indonesia. Sebelas Maret University (UNS) is one of the Institutions that also opens the BIPA program for foreign students who will study there. UNS through UPTP2B (Center of Language Service and Development) has been implementing this program since 2010. One of the BIPA learning program is given to the students from $K N B$ countries (Developing Country Partnerships). In the implementation of $B I P A$ learning, foreign students are distinguished at certain levels based on their ability to speak Indonesian from the lowest level (the basic) to the highest (the academic level), where the students are considered capable of reading, writing, and speaking in Indonesian.

BIPA as language learning is included in the second language learning. In this case, language learning is not a constructive process that occurs in the mind, but also as a process of making meaning and civilization in social practice with native language speakers (Kumpulainen \& Wray, 2002). Second language learning is hypothesized that oral interactions facilitate language acquisition (Long, 2017). This is intended that during the interaction, the students will receive feedback on the learning process. Logically, through the interaction, the students will gain understanding in expressing or interpreting the language. In addition, the success of the second language learning is determined by commitment, total involvement, physical, intellectual, and emotional responses of students (Brown, 2008).

The ability to write is very important in the process of language learning. Writing is a language skill that enables people to express their feelings and thoughts (Akinwamide, 2018). To be able to express something in Indonesian language, foreign speakers need to know the systematics of language and the use of language. Products produced by writing can be essays. 
In the discourse, there are terms of cohesion (unity) and coherence, both in paragraphs and intact essays. Both of them are the most important means for the readers to be able to understand the contents of the discourse. Cohesion and coherence of the discourse become a measure of readability of the contents of the discourse. Likewise, the discourse is in the form of narrative essays written by BIPA students. BIPA students are considered to have been able to write well and correctly if they can make their writing cohesively and coherently. BIPA students at Sebelas Maret University were the students who would take classes at the University. Therefore, this was very important for the students in the daily learning. Thus, anyone who read would be able to capture the meaning and content of the student's essay. To find out the extent to which BIPA students were able to write, the researchers were motivated to examine the forms of cohesion and coherence in the narrative essays of BIPA students.

\section{Literature Review}

Indonesian Language for Foreign Speakers $(B I P A)$ is an Indonesian language learning whom subjects are foreign speakers. $B I P A$ is seen more as a learning factor. People who are the subjects of $B I P A$ learning are foreigners, not native speakers of Indonesian language (Kusmiatun, 2016). The process of learning Indonesian Language for Foreign Speakers called $B I P A$ is the same as the learning process in general, which has a system arranged in such a way. Language learning materials and processes are tailored to the objectives of foreign students and aim to enable BIPA students to speak Indonesian and be familiar with Indonesian culture (Suyitno, Gatut Susanto, Musthofa \& Ary, 2017).

Cohesion and coherence are favorite studies according to linguists. Both concepts are traditionally related to the reading process which then becomes a tool for teaching how to write texts (Palmer, 1999). Language consists of form and meaning so that the relationship between forms in the language is called cohesion, and the relationship of meaning or semantic relationship is called coherence. Cohesion is divided into two types, namely grammatical cohesion and lexical cohesion (Halliday \& Hasan, 1976). On the other hand, the concept of coherence is based on the understanding of the recipient of the message/reader, assuming that the message conveyed is easy to understand (Brown \& Yule, 1983). A discourse is considered coherent when the ideas listed are related to each other in a regular order.

Narrative essays as part of a discourse are imaginary stories written in a series of interconnected events. Narrative essays are characterized by the existence of chronological time and narrative in a simple way (Kane, 2000). The story in the narrative essay is not entirely imaginative, but there are those that are factual that tell the events or everyday experiences (Sulistyo, 2013). Narrative stories are usually stories of fiction, nonfiction, fairy tales, folklore/fable stories, and so on (Sarwani, 2015).

\section{Research Method}

This study was a descriptive qualitative research using content analysis approach. This study aimed to obtain the data and describe the results containing meaning (Sugiyono, 2017). The data sources were the writing results of narrative essays of two Madagascar students of Indonesian Language for Foreign Speaker at UPTP2B Sebelas Maret University. The instrument used was notes to obtain the data related to the use of cohesion and coherence in 
the results of essays of the students of BIPA. The techniques of collecting the data were: 1) the technique of reading, 2) the technique of listening, 3) the technique of writing, and 4) the technique of compiling the research results. According to Miles and Huberman (1994), the data were analyzed with the stages of: the data collection, unitization, the data record, the data presentation, temporary conclusions, validation, and final conclusions.

\section{Result and Discussion}

Based on the writing results of narrative essays of the students of $B I P A$, it can be described and discussed as follows:

\subsection{Cohesion}

Cohesion is the connection of the outer elements of a text. Cohesion occurs when the interpretation of one element of the text depends on other elements so that one element cannot be truly understood without any other element. To find out more about cohesion, it is divided into the following sections:

\section{a. Lexical Cohesion}

The forms of cohesion in the grammatical aspect can be described as follows:

1. Reference

Reference is the essence of special information that is marked to be retrieved. It is in the form of referential meaning which is the identity of the object referred to. Reference is indicated by the presence of words and phrases or other grammatical units mentioned earlier. Here is a form of reference in the narrative essay of the students:

(1) ..., Seorang tentara pulang dari perang. Bajunya kotor dan robek, perutnya kosong. Dia berjalan dan berusaha meminta makanan dari orang-orang di desa....

(2) "Iya mas, saya kasihan dengan kamu, tetapi ibu sendiri tidak punya makanan..."

(3) Indonesia adalah negara yang memiliki budaya, suku-suku yang sangat beragam dan lingkunan yang sangat Indah yang menarik semua mata dunia dan untuk manikmati itu perlu waktu yang cukup panjang.

(4) ...Itu yang membuat saya senang ketika saya bertemu dengan orang Jawa Tengah dan Jogja di kota lain. Walaupun mereka tinggal di kota lain dengan gaya hidup baru dan lebih modern, identitasnya tidak bisa dipengaruhi dengan hal tersebut.

In the text above, the reference pronouns in part (1), namely dia and -nya refer to seorang tentara in the previous sentence. Section (2) of ibu refers to saya in the previous clause. Itu in section (3) refers to the phrase of budaya, suku-suku yang sangat beragam dan lingkungan. Section (4) of mereka refers to Jawa Tengah dan Jogja that can also be called the term of anaphora.

2. Substitution

Substitution is placement/replacement of something back with other elements. The form of substitution is in the form of certain language elements that replace the language elements that precede or follow it. 
(1) Dia sudah melewati banyak desa kecil, mencoba masuk ke semua rumah untuk meminta bantuan, tetapi tidak ada yang terima permintaan dia. Ada yang sampai menyuruh anjingnya untuk keluarkan tentara tersebut ke jalan, juga banyak yang bilang bahwa mereka sendiri tidak mempunyai makanan yang cukup.

In the text above, the phrase of semua rumah is replaced with ada in the next sentence. Then, in the next part, the same form is replaced with juga.

3. Ellipsis

Ellipsis is removal of an element. Imposing occurs when some important structural elements are eradicated and can only be recovered by referring to an element in the text that precedes it. This ellipsis is a cohesion in the form of the removal of certain constituents mentioned earlier.

(1) Hmmm, jadi ini sudah enak sekali, tetapi lebih enak lagi kalau ditambahkan sosis. Sosis ada di lemari, saya ambil. Ibu bilang dengan bangga. Langsung ambil dua bu, satu untuk saya satu untuk ibu. Setelah sopnya ditambahkan dengan sosis, tentara meminta kentang, sayur dan beras dengan cara yang sama.

In the text above, the removal is done in the part of jadi ini sudah enak sekali, tetapi lebih enak lagi kalau ditambahkan. Then, it is eradicated into the form of dengan cara yang sama. This is due to the meaning in the previous part that is the same as the form that is eradicated.

4. Conjunction

Conjunction is cohesion done by connecting one element with another element in the discourse. Conjunctions express certain meanings that indicate the preconditions for the presence of other components in the discourse.

(1) "Iya mas, saya kasihan dengan kamu, tetapi ibu sendiri tidak punya makanan..."

(2) “..., saya punya lemak mas, sebentar saya ambilkan”. Ibunya menjadi semakin penasaran dan semangat tentang memasak sop batu. Setelah sopnya ditambahkan lemak, tentaranya mencicipi lagi.

(3) Sebelumnya, kita tidak terbiasa makanan yang pedas, kita merasa tidak cocok dengan makananya. Kemudian setelah kita melewati tahap itu kita sudah mulai merasa cocok dan nyaman dengan semua keadaan dan memulai menikmati apa yang ada.

In the text above, there is a relationship that shows how two clauses or tables are combined. This amalgamation uses contradictory conjunctions in section (1) which are marked with the word of tetapi. Parts (2) and (3) use temporal conjunctions that are indicated by the use of Setelah, Sebelum, and Kemudian.

\section{b. Lexical Cohesion}

The forms of cohesion in the lexical aspect are described as follows:

1. Repetition

Repetition is repetition of lingual units (sounds, syllables, words, or parts of sentences) which are considered important to put pressure in an appropriate context. 
(1) ... Ibunya menjadi penasaran sekali dengan masakan tentara itu. Ibu mau tahu gimana memasak sop dari sebuah batu saja. Tentara mengaduk terus sopnya, setelah airnya sudah mendidih, dia mencicipi masakannya. Ibu, sop ini sudah lumayan enak, tetapi perlu tambah garam sedikit. Oh gitu, garam aja saya punya. Tentara masukin garamnya dan mencicipi lagi. Ibu, saya sering sekali memasak sop seperti ini. Percaya saya, ini jadi lebih enak lagi kalau bisa ditambahkan dengan satu sendok lemak. Apakah ibu punya? Oh gitu, saya punya lemak mas, sebentar saya ambil. Ibunya menjadi semakin penasaran dan semangat tentang memasak sop batu. Setelah sopnya ditambah lemak, tentara cicipi lagi. Hmmm, jadi ini sudah enak sekali, tetapi lebih enak lagi kalau ditambahkan sosis. Sosis ada di lemari, saya ambil. Ibu bilang dengan bangga. Langsung ambil dua bu, satu untuk saya satu untuk ibu. Setelah sopnya ditambahkan dengan sosis, tentara meminta kentang, sayur dan beras dengan cara yang sama. Ibunya menjadi semakin semangat untuk mengikuti proses memasak. Setelah sopnya jadi mereka makan sendiri. Ibu kaget sekali dan tidak percaya bisa memasak sop yang seenak itu dari sebuah batu aja.

In the text above, there is a repetition of the same form, namely sop and enak. The repeated section aims to bind one sentence to another.

\section{Synonym}

Synonym can be defined as another name for the same thing; or expressions whose meanings are more or less the same as other expressions. Synonym functions to establish meaningful relationships that are commensurate between certain words and other words in the discourse.

(1) Setelah mengalami tahap adaptasi, kita mulai bisa memahami budaya dan kebiasaan orang Indonesia dan akhirnya kita menyesuaikan diri dengan hal itu.

In the text above, the word of adaptasi is synonymous with menyesuaikan. Therefore, it is not necessary to reveal the same words over and over to give the same meaning.

3. Collocation

Collocation is certain associations in using word choices that tend to be used side by side. Collected words are words that tend to be used in a particular domain or network.

(1) Tidak masalah bu, saya bawa batu sendiri. Saya bisa memasak sop dari batu ini saja. Yang saya perlu itu hanya sebuah panci dan api.

In the text above, what is related to the word of memasak can be juxtaposed with the words of sup, panci, and api. The use is appropriate because it can be used together in sentences.

\subsection{Coherence}

Coherence is the connection between words or sentences in the text. Coherence is one element of the discourse that is used to explain a fact or event. Coherence is related to the relationship and interfaith order in the paragraph. A paragraph is not just a collection of 
sentences that stand alone. The combination of paragraphs is determined by harmonious inter-relationship.

Narrative essays produced by two Madagascar students showed the coherent parts. The form of cohesion contained in the sentences in each paragraph showed the integrity of a discourse. Although coherence was not always indicated in the completeness of the language elements, what the students conveyed in their writing could be captured by the reader. The researcher as the reader was able to understand what was conveyed by the two BIPA students in each of their essays.

\section{Conclusion}

Based on the analysis results of the narrative essays of the two Madagascar students of $B I P A$, the following cohesion forms were found: 1) grammatical cohesion consisted of reference, substitution, ellipsis, and conjunction; 2) lexical cohesion consisted of repetition, synonym, and collocation. In the form of coherence, the students were able to express their writing in a simple way to be able to be understood by the readers so that there was no deep understanding to capture the meanings that the students wanted to convey in their writing. Overall, there were still errors or mistakes in writing a few words and a series of sentences. This was because the students still had difficulties in implementing punctuations, capital letters, standard and non-standard forms in Indonesian.

\section{References}

Akinwamide, T.K. (2018). Enhanced Collaborative Teaching Method on The Performance of Students in Essay Writing Task. Budapest International Research and Critics Institute-Journal, 1(3) 84-90.

Brown, G. \& Yule, G. (1983). Discourse Analysis. Cambridge: Cambridge University Press. Brown, H.D. (2007). Principles of Language and Teaching ( $5^{\text {th }}$ Edition). New York: Pearson Education.

Destiani, Andayani, dan M. Rohmadi. (2018). Vocabulary Load on Two Mainstream Indonesian Textbooks for Foreign Learners: A Comparative Study. International Journal of Social Sciences \& Educational Studies. 5(2), 137-151.

Halliday, M.A.K. \& Ruqaiya Hasan. (1976). Cohesion in English. London: Longman.

Kane, T.S. (2000). The Oxford Essential Guide to Writing. New York: The Berkley Publishing Group.

Kumpulainen, K. \& Wray D. (Eds). (2002). Classroom Interaction and Social Learning: From Theory to Practice. New York: Routledge.

Kusmiatun, Ari. (2016). Mengenal BIPA (Bahasa Indonesia bagi Penutur Asing) dan Pembelajarannya. Yogyakarta: K-Media.

Long, M. H. (2017). Interaction in L2 Classrooms. The TESOL Encyclopedia of English Language Teaching.

Miles, Matthew B dan A. Michael Huberman. (1994). Qualitative Data Analysis. London: SAGE Publication.

Palmer, J.C. (1999). Coherence and Cohesion in the English Language Classroom: The Use of Lexical Reiteration and Pronominalisation. SAGE Publication RELC Journal, 30(2) 61-85. 
Sarwani, Ahmad. (2015). Narative Text Sebagai Sumber Belajar Mata Pelajaran Bahasa Inggris untuk Menumbuhkan Nilai Moral Peserta Didik. Lingua, 12(2) 243-254.

Sugiyono. (2017). Metode Penelitian Kualitatif. Bandung: Alfabeta.

Sulistyo, I. (2013). An Analysis of Generic Structure of Narrative Text Written by the Tenth Year Students of SMA Yasiha Gu. ETERNAL, 4(2) 169-181.

Suyitno, I., Gatut S., Musthofa K., \& Ary, F. (2017). Cognitive Learning Strategy of BIPA Students in Learning the Indonesian Language. IAFOR Journal of Language Learning. 3(2) $175-191$. 